\title{
Cost Differentials between E-Books and Print in Academic Libraries
}

\author{
Timothy P. Bailey, Amanda L. Scott, and Rickey D. \\ Best
}

Academic libraries continue to face funding pressures compounded by the need to provide students with access to electronic resources, both in journal and book formats. With space constraints and the need to repurpose library space to other uses, libraries must carefully examine the move to e-only formats for books to determine if the format makes reasonable economic sense.

A survey conducted at Auburn University at Montgomery (AUM) has confirmed for academic libraries the work of Gray and Copeland on e-books being more expensive than print for public libraries. For AUM, the mean cost for an e-book is significantly higher than for the print counterpart of that title. The cost differentials between the two formats show e-books as being consistently higher than print in initial price. This consistency holds true across all LC classifications, regardless of whether or not the title is published by a university press or a commercial press.

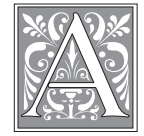

uburn University at Montgomery (AUM) is a regional, doctoral level V institution as defined by the Southern Association of Colleges and Schools Commission on Colleges. The institution has a student enrollment of approximately 5,000 undergraduate and graduate students and offers 34 undergraduate and 25 graduate degree programs.

Due to space constraints, the continued growth of the AUM Library's collections has been challenged. In an attempt to address this challenge, the library is considering altering the book selection process to favor e-books over print. The library has a history of using e-books, having subscribed to all of the netLibrary collections (now EBSCO e-books) and the ACLS Humanities collections. The library has also recently licensed access to Springer e-books collections. These collections were purchased or licensed as a group of titles and did not require individual selection for titles. Library emphasis has been to rely upon the e-book version of specific titles and to avoid duplicating those in print.

Timothy P. Bailey is Systems Librarian, Amanda L. Scott is Cataloging Librarian, and Rickey D. Best is Collection Development Librarian at Auburn University at Montgomery; e-mail: tbailey1@aum.edu, ascott20@aum.edu, rbest@aum.edu. The authors wish to express their appreciation to Samantha McNeilly of the AUM Library for her careful review and comments upon an earlier draft of this work. (C) 2015 Timothy P. Bailey, Amanda L. Scott, and Rickey D. Best. 
To address the need for monographs while at the same time limiting the requirement for increased storage space, in 2012 the AUM Library began considering a patron-driven acquisitions process. Prior to considering implementing such a scheme, the library analyzed processing costs associated with book acquisitions (\$ spent on cataloging salaries \& supplies in 2012 / \# of books cataloged in 2012). These costs were then compared to maintenance costs for e-book collections that the library subscribed to (maintenance cost/\# e-titles). In determining maintenance costs, because the library has participated in varied approaches (outright purchase and annual subscriptions), it was determined that the best approach would be to calculate for annual maintenance expenditures. To do this, the netLibrary collections that the library subscribed to were discounted from the equation as the collections were purchased with permanent access and no annual access fees. This required the library to pay retail plus 55 percent of the price to ensure ongoing access.

In processing costs, the library spent $\$ 13.29$ per print volume in 2012 and had a maintenance cost of $\$ 0.05$ ( $\$ 4,309$ in maintenance fees $/ 84,700$ e-book titles). This equates to a 30 percent differential between the processing costs for print and the maintenance costs for e-books.

Before committing to a patron-driven process, the library undertook an examination of book order requests from the faculty, who are the primary requestors on campus. First, the librarians sought to determine if requested titles were available electronically or were only in print. The principal objective in doing this was to determine if there is a sufficient cost differential between e-books and print. If so, it was felt that this would justify the change in selection practices to a predominant reliance upon e-books.

\section{Literature Review}

E-books are changing publishing rapidly. According to a report in The Huffington Post, four out of five publishers now produce e-books. A majority of publishers produce 50 percent of their titles as e-books, and nearly one-half produce 75 percent of their titles as e-books. Thirty-six percent of publishers derive greater than 10 percent of their revenue from e-books, a percentage that has doubled in the course of one year. Eighty percent of publishers still produce print versions of their e-titles, and 65 percent of the publishers have converted less than 50 percent of their backlist inventory into an e-book format. ${ }^{1}$

Peggy Johnson identifies the term "e-books" as referring to digital objects specifically designed to be accessible online and read on either a handheld device or a personal computer. ${ }^{2}$ Among the advantages to e-books are the ability to provide researchers access to the information at the time and location of their research need. ${ }^{3}$ Electronic books have become a significant part of a publisher's revenue stream. Nancy K. Herther reports that, during the first ten months of 2011, mass market book sales were down 33 percent, while e-book sales increased by more than 131 percent. The ease with which e-books have become available has significantly enhanced revenues for publishers. Ebooks now make up some 20 percent of publisher revenue, as opposed to slightly less than 1 percent in 2007. ${ }^{4}$ Noted by publishing consultant Joe Esposito, "With e-books, everything is being driven by the consumer market and the academic [market] has followed after that. ${ }^{5}$ Esposito contends the lag is due to the fact that "Many scholarly books have complex page makeup-charts, graphs, pictures - that present special challenges not handled well by current [e-publishing] standards."

\section{Libraries' Transition to E-books}

Libraries began the transition to electronic books through the purchase of groups of materials (NetLibrary, Safari, Ebrary, and others) making available significant collections of materials in an efficient manner. 
William H. Walters, in an article appearing in portal: Libraries and the Academy, reports many of the issues facing libraries with regard to the purchase or licensing of e-book content. Hindrances to widespread acceptance of e-books have been "publication delays between the print and the electronic versions, restrictive license terms (digital rights management), limitations of the use of e-books for interlibrary loan, the absence of standardized e-book formats and access mechanisms, and, the lack of transparency in publishers pricing and licensing models." 7

Walters observes that e-book selection, acquisition, and management "can be complex and expensive." He goes on to say that selection, acquisition, and management "become cost-effective only when libraries can take advantage of economies of scale-only when the necessary procedures can be made routine and delegated to support staff." 8

At the Triangle Research Libraries Network's Beyond Print Summit, it was noted that the loss of the discount available on print titles with electronic resources is a significant stumbling block for libraries, particularly for consortial purchases. The lack of ability for the sharing of e-book purchases was also cited as an obstacle by the implementation team of the Orbis Cascade Alliance in the implementation of a consortial DDA program. Flexibility in profiling and the short-term loan model used for triggering purchases provided support for the consortial approach-however, the pricing for the e-books remains an issue. ${ }^{9}$

Using data from Yankee Book Peddler's online ordering and selection database (GOBI), the typical cost of a single-user e-book is the equivalent to the list price of the hardcover version; and, for multiple simultaneous users, the cost becomes 150 percent of the hardcover list price. ${ }^{10}$

Ronald Jantz identifies a number of issues and notes the five requirements for ebooks to adequately be able to support academic library collections. The requirements include: "1. [Providing] more content suitable for research libraries including text books and scholarly monographs; 2. [Continuing] to improve the quality of e-book displays; 3. [Reducing] the weight of e-books [readers] to a manageable two pounds or less; 4 . [Supporting] open standards so that books from many different sources (publishers) can be downloaded to a variety of readers; and 5. [Improving] the process of finding and downloading e-books." 11

Requirements 1 and 3 have been well addressed. Requirement 2 has improved, and, with the implementation of Patron Driven Acquisitions, requirement 5, locating e-books can be solved by loading bibliographic records from the publisher's site into a library's ILS. Patrons are allowed to "order" the title via an algorithm based on a variety of factors including number of times viewed, length of time viewed, and the number of pages printed or downloaded or another agreed-upon standard. Additionally, traditional library book vendors such as Yankee Book Peddler, Baker \& Taylor, and Coutts offer options for discovering e-titles and placing orders. All that remains is the development and agreement of open standards for e-books.

In addressing the issue of technology and digital information, David Lewis identifies a strategy for libraries to transition to the digital environment. The elements of this strategy include a total migration from print to electronic collections to leverage the efficiencies this migration makes possible and the storage and retrieval of printed materials as needed. ${ }^{12}$ Lewis's approach reflects changes already taking place in libraries based upon changing institutional needs - specifically for space and in recognition of the influence electronic access has had on space needs related to library journal collections. Print journal collections at smaller institutions (such as AUM) have been reduced or discarded, and the libraries rely on being able to maintain electronic access. This changeover is now beginning to bring into question the legacy book collections. 
Lewis proposes that the library develop relationships with other campus departments to become a "primary informal learning space on campus" supporting teaching, research, and learning by implanting the tools, resources, and expertise made available through the library across multiple platforms. Finally, Lewis also proposes that the library migrate from the role of purchaser of materials to that of curator of content. ${ }^{13}$ Many of these proposals have been accomplished. Libraries are partnering with other groups on campus in sharing space for learning commons, with associated tutorial assistance; additionally, libraries have repositioned the information tools, such as single-search discovery systems and electronic reserves to allow these functions to be embedded into course management systems. As has been accomplished with electronic journals, libraries are serving as curators for content, rather than as permanent repositories for the information. With platform fees and user options for electronic books, the library has moved from a purchase, own, and store system to one akin to renting content. Even e-books purchased outright have some form of maintenance cost associated with them at this point in time.

\section{Pricing Models: Lease or Purchase?}

The decisions regarding purchase or subscription of individual titles (or collections) have impacts for library budgets, as do access options. As reported in EduServ's 2010 e-book survey, outright purchase is the preferred option for acquisition, as opposed to subscription. The reasons given are a) outright purchase is easier to budget for; $b$ ) the purchase is easier to administer than is a subscription; and c) clarity of ownership. ${ }^{14}$ Only when titles are rapidly outdated was a subscription preferred.

According to Walters, e-books are always leased, not purchased. He describes three kinds of leases available to libraries: a) annual access: the library pays a fee for one year's access, with the option to renew the lease; b) perpetual access: the library pays a one-time fee, often along with an annual platform or access fee; and c) pay per use: the library is charged based upon the number of uses (titles viewed, pages viewed, and so on), and the library may also pay an annual platform fee. ${ }^{15}$ In addition, there is the consideration of whether access is provided simultaneously for multiple users or is single use only.

In fact, the publishers of academic content have experimented with a variety of pricing models, some of which do allow libraries to own content outright. Among these pricing models is the purchase of a collection of e-book titles at a substantial discount. The university owns these titles but is faced with adding individual titles when a superseding edition is published. In some cases, discounts are offered for collections, but individual title pricing for e-books is significantly higher than print. Subscription models also exist, whereby libraries can subscribe to collections and, when a title is updated, receive the new content as part of their subscription price. Models of this practice appear with the vendors Ebrary (Academic Complete), Safari Tech Books Collection, and Credo Reference. ${ }^{16}$

Peter Brantley proposes "a subscription service to a comprehensive set of books for a modest fee, usually near $\$ 10$ a month for a base level membership, with streaming access to titles that are convertible to downloadable e-book sales." ${ }^{17}$ Brantley states "For publishers, offering a subscription alternative would have another outcome: it would make library borrowing unattractive .... [a subscription service] would nudge one of the most attractive segments of the library population into a consumer market: heavy readers, who heretofore have accepted the hassles of library borrowing rather than face the monetary burden of having to purchase individual titles." 18 The impact of Brantley's argument would be a return to the subscription library concept. 


\section{Patron-Driven Acquisitions}

The time has come to consider the necessity of purchasing e-books at the individual title level. In doing this, libraries are moving toward Patron- (or Demand-) Driven Acquisitions (PDA/DDA), reducing if not eliminating the traditional library approach of acquiring materials "just in case" to allowing the user to purchase materials directly "just in time." ${ }^{19}$ PDA or DDA is an implicit recognition that librarians have not been as successful in selecting for patron needs as we would like to believe-according to countless studies showing how the majority of circulations are covered by a small coterie of titles.

After implementing a PDA program at California State University-Fullerton, William Breitbach and Joy Lambert found that the average purchase price for e-book titles purchased through the program was $\$ 73.93$. However, titles were not purchased until after three short-term loans occurred, and which incurred additional fees, driving the average cost per title up to $\$ 95.34$. In 2008 , the average price for an academic book was $\$ 68.01$, only slightly lower than the purchase price from the PDA program under discussion. It is not known whether or not e-book prices offered through PDA programs are the same as they would be if they were purchased through a traditional print process. ${ }^{20}$

Rebecca Schroeder documents multiple versions of PDA for print items (based on faculty requests, a suggestion program, ILL, and holds) and a PDA program for ebooks. She found that average cost for an e-book ordered through the PDA program was $\$ 76.78$, and the average cost for an e-book ordered through "traditional collection development" was $\$ 103.65$, a difference of 35 percent. The mean cost for print books purchased through the various print PDA programs ranged from $\$ 15.43$ to $\$ 41.10$, and the mean for print books ordered through "traditional collection development" was \$37.05. The average prices of e-books were considerably higher than those for print books in this study. This could be due to the electronic versions being more expensive than their print equivalents or due to the titles selected as e-books being more expensive in any format. It is likely that most, if not all, of the purchases documented in this study are for unique titles, so it is impossible to draw any definitive conclusions regarding the price differential between e-books and their print equivalents. Schroeder's data also demonstrates that the average cost per use for titles ordered through some form of PDA were similar to or less expensive than those ordered through traditional methods. ${ }^{21}$

Robert Johnson reports on pricing models for e-books purchased through PDA programs derived from his library's investigation prior to implementing a PDA program. According to him, there are different models, starting with charging hardcover price for a single-user purchase. E-books can also be more expensive than print: at least 1.5 times the hardcover price for a single user. Purchasing a license for multiple simultaneous users is even more expensive. ${ }^{22}$ Johnson's findings may show the most modest price increase for e-books considered en masse, depending on how many titles' prices were equal to hardcover prices. Nevertheless, it is clear that Johnson's examination found at least a slight price increase for e-books, similar to the results reported by Lippincott et al. earlier in this review.

Prices for titles purchased through PDA programs may or may not map directly onto those for titles purchased through a traditional acquisitions model. It is not known whether or not libraries are charged more, less, or the same when they acquire titles via PDA programs, although Schroeder's findings do cause one to wonder if PDA titles are more expensive.

\section{Price Comparison}

Publishers continue to be in a state of flux with regard to the pricing of e-books. In her column Foreword: The E-book Pricing Conundrum, Rachel Deahl notes that publishers make as much money on Kindle editions as print editions since Amazon pays 
the same discount to publishers for e-books that it does for print. Kindle editions of bestsellers, Deahl asserts, are sold at a 60 percent discount by Amazon versus a 45 percent discount on print. ${ }^{23}$ While this may be true for bestsellers, it does not apply for the typical content purchased by academic libraries. As noted earlier, Lippincott et al. report that e-book prices typically start at the hardcover full price for a single user in Yankee Book Peddler's GOBI database. ${ }^{24}$

David Gray and Andrea Copeland's per-title cost and use comparison of e-book and print titles in a public library setting confirms that the average price per purchased print titles is less (\$15.68) than that of purchased e-books $(\$ 17.80) .{ }^{25}$ Possibly the greatest limitation of the study is that "Public libraries... are expected to fill user demands for popular... materials, and... multiple copies... are purchased or leased." ${ }^{26}$ Indeed, multiple copies of certain works have come to be expected; it is anticipated that public library patrons will expect e-books to become one of many formats available. Thus, content is generally duplicated in the popular press titles surveyed. Circulation of e-books was found to be similar or comparable to that of printed works, despite a larger number of printed copies being available; this may be due to the ease with which e-books are circulated. Gray and Copeland find that purchased print books have a per-circulation cost of $\$ 1.11$ versus $\$ 1.15$ for e-books and $\$ 1.17$ per title when purchased and leased works' costs are combined. While the study was limited in scope, due to factors such as time period covered, differing circulation periods for the different formats, "hidden" costs such as processing fees and storage costs, and collection scope and guidelines, it demonstrates that printed works are still of lesser cost than electronic titles. ${ }^{27}$ This is consistent with the findings of the AUM Library when including processing and maintenance costs as a part of the consideration.

The Douglas County Libraries (Colorado) also find e-books to be more expensive than print. In their monthly list of selected price comparisons, frequently drawn from bestseller lists, they show that, when a title is available to libraries in both electronic and print formats, the e-book is usually more expensive. (They also demonstrate that libraries often pay higher prices for e-books than consumers do. $)^{28}$ Though these reports are not a formal study, they do support Copeland and Gray's findings.

Walters notes that "individually acquired e-books cost more than printed books" and that "Few scholarly e-books sell for less than the hardcover list price." ${ }^{29}$ This is confirmed by Yankee Book Peddler's Annual Book Price Update (September 2012), which shows an average print price of $\$ 78.23$ (paper preferred), $\$ 83.59$ (cloth preferred), while the average price of an e-book was $\$ 95.14$, an increase of 21.6 percent. ${ }^{30}$

The publication of monographs in varying formats led us to review pricing differentials between print and e-book publications for university presses and for commercial publishers. Oxford University Press (OUP) debuted its platform for electronic monographs in 2003, the first university press to do so. It also attempted to implement a shared digital platform for smaller university presses with the same academic mission as itself. ${ }^{31}$

\section{More on Price Comparison: Should Electronic Be Cheaper Than Print?}

Through focus group interviews with academic librarians, Chris Armstrong and Ray Lonsdale learn that librarians are concerned with the prices of e-books. Librarians suspect that e-books are less expensive to produce than print books, yet they find that e-books carry a "premium price" and possibly include annual charges of some sort. E-books often carry the extra price of printing before patrons use a section of the book, a cost that is either passed on to the patron or added to what the institution is already paying to purchase or lease the book in the first place. ${ }^{32}$

While many believe that e-books should be cheaper than print, there are a number of factors that influence ultimate pricing. While vendors such as Amazon offer low 
prices for e-books to gain market share for their e-reader platform (Kindle), production costs such as editing and formatting are the same for the book, regardless of whether it is printed or published digitally. Additionally, e-books have unique costs such as online hosting, server and network maintenance, reformatting for multiple formats, customer service, and technical support. Publishers must also continue to pay editors; and prepress costs, as cited by Walters, are the same for both print and e-formats ( $\$ 8$ to $\$ 11$ per page). Author royalties (between 10 and 15 percent of net sales revenues) also need to be taken into consideration. ${ }^{33}$

As Kelly Lynch reports, a review of pricing options for e-books is currently underway. At the Frankfurt Book Fair, the standard price for an e-book is cited currently at $\$ 9.99$ (note: this is in part because of Amazon's pricing model but is true generally for mass market and not academic titles). The e-book price is generally 25 percent below the paperback price and far less than the hardcover price. Under consideration at the Frankfurt Book Fair is whether or not the $\$ 9.99$ price is always an appropriate price. Among the elements affecting pricing are that production costs for e-books are less than print, but other factors influence ultimate pricing as well. ${ }^{34}$ In a session discussion at Frankfurt, Richard Charkin articulated the position that e-books are distinct products and not necessarily of lesser value - therefore, "the price of an e-book should be constantly adjusted during the book's life cycle in order to generate maximum profit," as Lynch says regarding Mohammed and Eglen's position. ${ }^{35}$ In short, publishers will see and be able to adjust pricing based upon demand for a title. Demand will also have a significant impact on backlist titles.

While the economic issues the publishers face are real, libraries also face those same issues. An examination of the data developed by the AUM Library indicates that pricing differentials between e-books and print for academic titles are substantial.

\section{AUM Library Survey Data}

To determine cost effectiveness for the purchase of books, the AUM Library examined book order requests submitted by the faculty for the fall 2012 semester. A total of 462 requests were examined, with each request representing a unique title. Within the AUM Library's profile with Baker \& Taylor, paperback is identified as the preferred format for print materials. New title announcement slips are received and routed to the faculty - if a paperback issue of the work has been published, the slip received is for paperback.

The titles requested by the faculty were then examined to determine availability of an e-version of the title. Of the unique titles, 57 percent (264) were also available in an electronic format. Pricing was compared between the print version and the e-version, and mean pricing was determined. This was done for books that were university press titles as well as those that were commercial press.

To determine price differentials, Baker \& Taylor's Title Source 3 product was used. This product was chosen because it contained information on e-books available through EBSCO and Ebrary, two other acquisition vendors. Title Source 3 is a free, searchable database of bibliographic acquisitions information for U.S. publications, available from Baker \& Taylor. Among the information contained in Title Source 3 is ordering information, including pricing and discounting. Since the completion of the analysis, Title Source 3 has been upgraded into the product Title Source 360.

In determining price differentials, titles that were examined included both print and electronic format. Retail pricing was used as the basis for comparison, as some titles are not discounted. The analysis was based upon single-user-only pricing. These data were used to be consistent with current library policy which, due to space constraints, prohibits the purchase of multiple print copies. 
Order requests were broken down by LC classification, and pricing for print and e-book formats were determined. As one would expect, requests for titles from the faculty mostly align with the LC classes of the subjects being taught by the faculty member. The notable distinction, however, is for faculty in the department of history who, proportionately, order more titles from outside the history classifications (D-F) than do the faculty of other departments. The requests are also linked to the size of the faculty in the various disciplines; with ten faculty members in history and only one in music, it seems logical that the ordering preference would be more heavily weighted toward history than music (as was the case, with 121 history related titles requested versus 5 music titles). Differentials were noted where one format was different in price than the other. Table 1 provides the mean pricing for print, electronic, and price differentials for the entire requests broken out by LC classification. In those instances where a price differential represents a negative number, the actual cost of the e-title was cheaper than that of the print.

For the total number of requests, the print titles had a mean price of $\$ 53.50$ while the electronic equivalents had a mean price of $\$ 73.50$. The price differentials between e-books and print titles came to $\$ 19.17$, with e-books being generally more expensive. Of the 264 e-book titles, in only 44 instances was the e-book price less than the print cost. In these cases, the discounts ranged from .01 to $\$ 170.00$. The mean discount was $\$ 10.28$ for the 44 titles. As a percentage, there exists a 35.11 percent price differential for e-books over print for all books, both university press and non-university press. This is consistent with the data provided by Lippincott et al. for the Triangle Research Library Network's summit.

The results were also examined to determine if there was a difference in pricing between print and electronic titles for university press publications and non-university press titles. The non-university press titles included commercial publishers,

\begin{tabular}{|l|c|c|c|c|c|}
\hline \multicolumn{7}{|c|}{ TABLE 1 } \\
\hline $\begin{array}{l}\text { LC } \\
\text { Classification }\end{array}$ & $\begin{array}{c}\text { \# Print } \\
\text { Titles* }\end{array}$ & $\begin{array}{c}\text { Average } \\
\text { Print Price }\end{array}$ & $\begin{array}{c}\text { \# E-book } \\
\text { Titles }\end{array}$ & $\begin{array}{c}\text { Average } \\
\text { E-book Price }\end{array}$ & $\begin{array}{c}\text { Mean Price } \\
\text { Differential All }\end{array}$ \\
\hline BF & 22 & $\$ 62.18$ & 15 & $\$ 78.46$ & $\$ 28.90$ \\
\hline BJ-BT & 8 & $\$ 44.35$ & 4 & $\$ 52.23$ & $\$ 19.76$ \\
\hline C-D & 66 & $\$ 57.44$ & 42 & $\$ 85.66$ & $\$ 22.10$ \\
\hline E-F & 55 & $\$ 37.69$ & 32 & $\$ 50.22$ & $\$ 9.60$ \\
\hline G & 12 & $\$ 35.64$ & 4 & $\$ 71.74$ & $\$ 41.39$ \\
\hline HA-HX & 82 & $\$ 66.64$ & 51 & $\$ 73.29$ & $\$ 5.01$ \\
\hline J-K & 27 & $\$ 42.15$ & 15 & $\$ 84.26$ & $\$ 50.05$ \\
\hline L & 75 & $\$ 56.28$ & 44 & $\$ 70.28$ & $\$ 19.88$ \\
\hline M & 5 & $\$ 34.79$ & 3 & $\$ 46.66$ & $\$ 1.66$ \\
\hline P & 80 & $\$ 44.84$ & 38 & $\$ 75.41$ & $\$ 23.31$ \\
\hline Q & 11 & $\$ 92.33$ & 6 & $\$ 119.35$ & $\$ 25.21$ \\
\hline R & 13 & $\$ 58.66$ & 6 & $\$ 87.14$ & $\$ 42.81$ \\
\hline T-Z & 6 & $\$ 49.15$ & 4 & $\$ 41.50$ & $\$ 2.76$ \\
\hline Total & $\mathbf{4 6 2}$ & $\$ \mathbf{5 3 . 3 5}$ & $\mathbf{2 6 4}$ & $\$ 73.78$ & $\$ 19.17$ \\
\hline$*$ The average price for print includes all titles, including those without e-versions. \\
\hline
\end{tabular}




\begin{tabular}{|c|c|c|c|c|}
\hline \multicolumn{5}{|c|}{$\begin{array}{c}\text { TABLE } 2 \\
\text { Mean Prices and Price Differentials by LC Class and Format for University } \\
\text { Press Publications }\end{array}$} \\
\hline $\begin{array}{l}\text { LC } \\
\text { Classification }\end{array}$ & $\begin{array}{l}\text { \# University } \\
\text { Press Print } \\
\text { Titles }\end{array}$ & $\begin{array}{l}\text { Average } \\
\text { University } \\
\text { Press Print } \\
\text { Price }\end{array}$ & $\begin{array}{l}\text { Average } \\
\text { University } \\
\text { Press E-book } \\
\text { Price }\end{array}$ & $\begin{array}{l}\text { Mean Price } \\
\text { Differential } \\
\text { University } \\
\text { Press E-books }\end{array}$ \\
\hline $\mathrm{BF}$ & 7 & $\$ 39.28$ & $\$ 66.71$ & $\$ 27.43$ \\
\hline BJ-BT & 3 & $\$ 30.63$ & $\$ 27.97$ & $-\$ 2.67$ \\
\hline $\mathrm{C}-\mathrm{D}$ & 23 & $\$ 50.72$ & $\$ 83.12$ & $\$ 32.40$ \\
\hline E-F & 23 & $\$ 39.34$ & $\$ 50.39$ & $\$ 11.05$ \\
\hline $\mathrm{G}$ & 3 & $\$ 27.15$ & $\$ 82.33$ & $\$ 55.19$ \\
\hline HA-HX & 11 & $\$ 81.22$ & $\$ 80.90$ & $-\$ 0.32$ \\
\hline $\mathrm{J}-\mathrm{K}$ & 13 & $\$ 33.40$ & $\$ 79.22$ & $\$ 45.82$ \\
\hline $\mathrm{L}$ & 11 & $\$ 72.26$ & $\$ 80.44$ & $\$ 8.18$ \\
\hline $\mathrm{M}$ & 2 & $\$ 35.00$ & $\$ 37.50$ & $\$ 2.50$ \\
\hline $\mathrm{P}$ & 13 & $\$ 34.01$ & $\$ 55.52$ & $\$ 21.51$ \\
\hline Q & 2 & $\$ 44.98$ & $\$ 60.58$ & $\$ 15.61$ \\
\hline $\mathrm{R}$ & 2 & $\$ 29.97$ & $\$ 56.96$ & $\$ 26.99$ \\
\hline $\mathrm{T}-\mathrm{Z}$ & 2 & $\$ 27.48$ & $\$ 33.00$ & $\$ 5.53$ \\
\hline Total & 115 & $\$ 41.96$ & $\$ 61.13$ & $\$ 19.17$ \\
\hline
\end{tabular}

professional associations, and university departmental publications not published by a university press. Table 2 provides an examination of university press publications in print and electronic formats.

With the exception of religion and philosophy (BJ-BT) and the social sciences (H$\mathrm{HV})$, e-books were more expensive than their print counterparts. Only in the H-HVs were e-books cheaper, on average, with an overall price differential of $-\$ 0.32$ per title. The greatest price differentials were found in the HQ (family, women, and marriage) and HV classifications (social pathology, criminology) with HQs having price differentials for e-books of $-\$ 2.00,-\$ 149.00$ and $-\$ 170.00$, for an average price differential of $-\$ 107.00$. The HVs had price differentials of $-\$ 11.80$ for the e-books in this classification. For university press titles, there exists a 45.11 percent price differential for e-books over print.

The data was examined to determine if a price difference existed between print and e-books for non-university press titles. As indicated in table 3, only six LC classifications had no or slightly negative price differentials between print and e-books. Of these classes (M-Music, G-Geography/Anthropology, and T-Z, which includes technology, home economics, military administration, and library science), only music had a negative price differential of $-\$ 0.01$. The remainder was neutral in terms of differentials. The average price differential for non-university press titles was $\$ 25.76$, compared to an average price differential for university press publications of $\$ 19.17$. As a percentage, e-books from non-university press titles were 43.61 percent more expensive than were the print version.

Average prices for print books were cheaper for university press publications, averaging $\$ 41.96$ versus $\$ 59.07$ for non-university press publications. E-book prices were 


\begin{tabular}{|l|c|c|c|c|}
\hline \multicolumn{5}{|c|}{ TABLE 3 } \\
\hline Field & $\begin{array}{c}\text { \# Non- } \\
\text { University } \\
\text { Press Print } \\
\text { Titles }\end{array}$ & $\begin{array}{c}\text { Average Non- } \\
\text { University } \\
\text { Press Print } \\
\text { Price }\end{array}$ & $\begin{array}{c}\text { Average Non- } \\
\text { University Press } \\
\text { E-book Price }\end{array}$ & $\begin{array}{c}\text { Mean Price } \\
\text { Differential Non- } \\
\text { University Press } \\
\text { E-books }\end{array}$ \\
\hline BF & 8 & $\$ 58.55$ & $\$ 88.74$ & $\$ 30.19$ \\
\hline BJ-BT & 1 & $\$ 37.95$ & $\$ 125.00$ & $\$ 87.05$ \\
\hline C-D & 19 & $\$ 79.09$ & $\$ 88.72$ & $\$ 9.63$ \\
\hline E-F & 9 & $\$ 43.88$ & $\$ 49.78$ & $\$ 5.90$ \\
\hline G & 1 & $\$ 39.95$ & $\$ 39.95$ & $\$ 0.00$ \\
\hline HA-HX & 40 & $\$ 64.73$ & $\$ 71.20$ & $\$ 6.47$ \\
\hline J-K & 2 & $\$ 39.45$ & $\$ 117.00$ & $\$ 77.55$ \\
\hline L & 33 & $\$ 43.11$ & $\$ 66.89$ & $\$ 23.78$ \\
\hline M & 1 & $\$ 65.00$ & $\$ 64.99$ & $-\$ 0.01$ \\
\hline P & 25 & $\$ 65.30$ & $\$ 89.55$ & $\$ 24.25$ \\
\hline Q & 4 & $\$ 118.73$ & $\$ 148.74$ & $\$ 30.01$ \\
\hline R & 4 & $\$ 62.21$ & $\$ 102.24$ & $\$ 40.02$ \\
\hline T-Z & 2 & $\$ 50.00$ & $\$ 50.00$ & $\$ 0.00$ \\
\hline Total & $\mathbf{1 4 9}$ & $\$ 59.07$ & $\$ 84.83$ & $\$ 25.76$ \\
\hline
\end{tabular}

cheaper for university press titles as well, averaging $\$ 60.89$ in comparison with $\$ 84.83$ for non-university press titles. This suggests that university presses are subsidized to some degree by their home institution. As identified by the Association of American University Presses, university presses "focus upon a mission to publish works of scholarly, intellectual, or creative merit, often for a small audience of specialists or a regional community of interest." ${ }^{36}$ University presses support the publication of scholarly works that a commercial, for-profit press would often not publish.

Because the university and non-university press averages were computed by using equally weighted means (also known as arithmetic means), weighted means were also computed for the titles. This was done to compensate for the differing number of titles for each classification range, so that classes with many books carry more weight in the

\begin{tabular}{|l|c|c|c|c|c|c|}
\hline \multicolumn{7}{|c|}{ TABLE 4 } \\
\hline Press & $\begin{array}{c}\text { Overall } \\
\text { Weighted } \\
\text { Mean: } \\
\text { Print }\end{array}$ & $\begin{array}{c}\text { Overall } \\
\text { Arithmetic } \\
\text { Mean: } \\
\text { Print }\end{array}$ & $\begin{array}{c}\text { Overall } \\
\text { Weighted } \\
\text { Mean: } \\
\text { E-book }\end{array}$ & $\begin{array}{c}\text { Overall } \\
\text { Arithmetic } \\
\text { Mean: } \\
\text { E-book }\end{array}$ & $\begin{array}{c}\text { Overall } \\
\text { Weighted } \\
\text { Price } \\
\text { Differential } \\
\text { Mean }\end{array}$ & $\begin{array}{c}\text { Overall } \\
\text { Arithmetic } \\
\text { Mean: } \\
\text { E-book }\end{array}$ \\
\hline $\begin{array}{l}\text { University } \\
\text { Press }\end{array}$ & $\$ 46.60$ & $\$ 41.96$ & $\$ 67.57$ & $\$ 61.13$ & $\$ 20.97$ & $\$ 19.17$ \\
\hline $\begin{array}{l}\text { Non- } \\
\text { University } \\
\text { Press }\end{array}$ & $\$ 60.78$ & $\$ 59.07$ & $\$ 78.56$ & $\$ 84.83$ & $\$ 17.78$ & $\$ 25.76$ \\
\hline
\end{tabular}


final averages than classes with few books. The print, e-book, and differential averages for each LC Classification were weighted by the number of books in each class. Table 4 shows the weighted means in comparison with the print and e-book arithmetic means for university and non-university press publications.

As a final measure of analysis, an examination was undertaken to compare average prices and price differentials between print and e-books in the LC classifications for the humanities, social sciences, and sciences. As table 5 indicates, the humanities are the least expensive in terms of mean cost per print title, but they have an average e-book cost slightly higher than the social sciences. As one would expect, the sciences are the most expensive in terms of average cost, both for print and for electronic books.

\begin{tabular}{|l|c|c|c|c|}
\hline \multicolumn{5}{|c|}{ TABLE 5 } \\
Field Price Differentials \\
\hline $\begin{array}{l}\text { LC } \\
\text { Classification }\end{array}$ & \# Print Titles & $\begin{array}{c}\text { Average Print } \\
\text { Price }\end{array}$ & $\begin{array}{c}\text { Average } \\
\text { E-book Price }\end{array}$ & $\begin{array}{c}\text { Mean Price } \\
\text { Differential All }\end{array}$ \\
\hline Humanities & 45 & $\$ 51.99$ & $\$ 73.54$ & $\$ 21.55$ \\
\hline Social Sciences & 203 & $\$ 54.42$ & $\$ 72.72$ & $\$ 18.30$ \\
\hline Sciences & 16 & $\$ 64.29$ & $\$ 87.81$ & $\$ 23.52$ \\
\hline Total & 264 & $\$ 54.60$ & $\$ 73.78$ & $\$ 19.17$ \\
\hline
\end{tabular}

\section{Survey Analysis}

Following an examination of the book order requests by the Auburn University at Montgomery faculty, the data appear to support Gray and Copeland's assertion that print books are cheaper than e-books, not only for public libraries but also for academic libraries. The AUM data indicate the following:

First, that the publication of e-book versions being published nearly simultaneously with the print editions has significantly increased. The Baker \& Taylor Title Source 3 software indicated that 57.15 percent of the 462 titles examined had an e-book counterpart that was available either immediately or within a sixty-day period. Long delays in publication of an e-version are no longer the norm.

Second, e-books are not uniformly cheaper in terms of initial capital outlay than the print counterpart. The initial outlay for purchasing or licensing access to the electronic version of a book does not address additional costs associated with maintaining access (maintenance costs, equipment costs required to maintain access, and so on).

Third, libraries must measure the physical processing as well as storage costs for print against the ongoing maintenance costs for continued access to the electronic versions, and that we must develop a better understanding of the uses being made of e-books.

Finally, libraries must be funded adequately to support the convenience costs associated with acquiring and making e-books accessible, with the recognition that e-book costs are generally not one-time outlays of funds but require ongoing maintenance to ensure continued access.

Continued research is required to truly understand the value of e-books for our users. While some use studies have been undertaken for e-books, a more thorough study along the lines of that conducted by Allen Kent at the University of Pittsburgh ${ }^{37}$ would be useful, especially in light of the growing importance of patron-driven acquisition programs.

\section{Future Steps}

Upon the completion of the analysis of the data, the library was informed of a forthcoming budget reduction of 20 percent in its O\&M funding. The forthcoming reduction will 
impact monographic acquisitions for the next budget year (October 1-September 30). As a result of this, consideration is not being given to moving all book acquisitions to acquiring titles in an electronic format. The financial impact of a) not receiving a discount on e-titles and b) the requirement of additional platform fees and maintenance is problematic. Space considerations remain a part of the considerations for moving more specifically to individual e-title access. However, the library has conducted a vigorous weeding program resulting in the withdrawal of more than 20,000 titles during the past academic year (2011-2012). Faced with the overall budget reductions for the new fiscal year (2013-2014), a determination has been made to delay implementation of a patron-driven acquisitions option. A review of finances will be undertaken in spring of 2014 to determine if implementation of patron-driven acquisitions can be take place during the fiscal year. Consideration is being given to move to individual e-title selection, particularly for courses that are designated for distance learning.

\section{Conclusion}

The continued migration of publishing to electronic format for books holds significant challenges for small to mid-sized academic libraries that are in an unstable and inconsistent economic environment. The movement to a predominantly e-only format for information is increasing the pressures upon academic libraries to be able to provide access to the digital resources, while those resources are in a pricing model reminiscent of the serials pricing models that have bedeviled libraries for decades. The continuing access fees for e-books being applied by many publishers are creating an unstable model for libraries to be able to maintain financial support for them, and the failure to discount e-titles are impacting library purchasing power.

Given the pressures cited above, PDA seems a reasonable alternative for continuing the development of the library's collections while at the same time providing resources that our users want and are willing to use. This is not to say that librarians should abandon the job of selecting materials-librarians select items for the long term, as opposed in many cases to our users' selection of materials to satisfy immediate needs. Recognizing the increased and ongoing costs that are associated with e-books will result in significantly decreased purchasing power on the part of the library. If, however, libraries are able to demonstrate an improved return on investment by increased usage of materials, they will be able to make a stronger case for additional funding to the university administration.

\section{Notes}

1. "How E-Books are Changing Publishing (INFOGRAPHIC)," The Huffington Post (Oct. 5, 2012), available online at www.huffingtonpost.com/2012/10/05/ebook-shapes-publishinginfographic_n_1943067.html [accessed 4 September 2013].

2. Peggy Johnson, Fundamentals of Collection Development and Management, 2nd ed. (Chicago: American Library Association, 2009), 109.

3. Sarah K. Lippincott et al., "Librarian, Publisher, and Vendor Perspectives on Consortial E-Book Purchasing: The Experience of the TRLN Beyond Print Summit" Serials Review 38 (Mar. 2012): 3-11.

4. Nancy K. Herther, "Ebooks Herald the Future of 21st-Century Publishing," Searcher 20, no. 2 (Mar. 2012): 12-54.

5. Ibid., 49.

6. Ibid.

7. William H. Walters, "E-books in Academic Libraries: Challenges for Acquisitions and Collection Management," portal: Libraries and the Academy 13, no. 2 (Apr. 2013): 187-211.

8. Ibid., 190.

9. Jill Emery, "The Demand Driven Acquisitions Pilot Project by the Orbis Cascade Alliance: An Interview with Members of the Demand Driven Acquisitions Implementation Team," Serials Review 38 (2012): 133.

10. Lippincott et al., "Librarian, Publisher, and Vendor Perspectives," 4. 
11. Ronald Jantz, "E-Books and New Library Service Models: An Analysis of the Impact of E-Book Technology on Academic Libraries," Information Technology and Libraries 20, no. 2 (June 2001): 104-12.

12. David W. Lewis, "A Strategy for Academic Libraries in the First Quarter of the 21st Century," College E Research Libraries 68, no. 5 (Sept. 2007): 418-34.

13 Ibid., 420.

14. EduServ e-Book Survey (S.1.: EduServ, 2010), available online at www.eduserv.org.uk/ / media/Eduserv\%20areas/LNS/information/ebook\%20survey\%202010\%2008.ashx [accessed 5 September 2013].

15. Walters, "E-Books in Academic Libraries," 191.

16. Rebecca Schroeder and Tom Wright, "Electronic Books: A Call for Effective Business Models," New Library World 112, no. 5/6 (June 2011): 215-21.

17. Peter Brantley, "Unsubscribing to the Library," PWxyz: The Blog of Publishers Weekly (Dec. 14, 2012), available online at http://blogs.publishersweekly.com/blogs/PWxyz/2012/12/14/ unsubscribing-to-th-Library/ [accessed 20 December 2012].

18. Ibid.

19. Numerous articles have been written recently regarding the migration to patron-driven acquisitions models for e-books. William $\mathrm{H}$. Walters has identified potential downsides to PDA in his article "Patron-Driven Acquisitions and the Educational Mission of the Academic Library" published in Library Resources E Technical Services 56, no. 3 (July 2012): 199-213; Karen Fischer et al. have identified the utility and effectiveness in PDA in their article "Give 'Em What They Want: A One-Year Study of Unmediated Patron-Driven Acquisition of e-Books" in College and Research Libraries 73, no. 5 (Sept. 2012): 469-92; and Douglas Jones has addressed issues of patrondriven acquisitions for both print and e-books through the use of a selective approval plan at the University of Arizona that is supplemented by librarian selection in "On-Demand Information Delivery: Integration of Patron-Driven Acquisition into a Comprehensive Information Delivery System" in Journal of Library Administration 51, no. 7/8 (Oct. 2011): 764-76.

20. William Breitbach and Joy E. Lambert, "Patron-Driven Ebook Acquisition," Computers in Libraries 31, no. 6 (July 2011): 17-20.

21. Rebecca Schroeder, "When Patrons Call the Shots: Patron-Driven Acquisition at Brigham Young University," Collection Building 31, no. 1 (2012): 11-14.

22. Robert Johnson, "Purchasing Options in Patron-Driven Acquisitions," Against the Grain 23 (June 2011): 14-16.

23. Rachel Deahl, "Foreword: The E-book Pricing Conundrum: Who Makes What on the Sale of E-books," Publishers Weekly 256, no. 19 (May 11, 2009): 4.

24. Lippincott et al., "Librarian, Publisher, and Vendor Perspectives," 4.

25. David J. Gray and Andrea J. Copeland, "E-Book Versus Print: A Per-Title Cost and Use Comparison of a Public Library's Popular Titles," References E User Services Quarterly 51, no. 4 (Summer 2012): 334-39.

26. Ibid., 338 .

27. Ibid.

28. Douglas County Libraries, "Douglas County Experiment/Model," available online at http:// evoke.cvlsites.org/resources-guides-and-more/douglas-county-experiment-model/ [accessed 23 September 2013].

29. Walters, "E-books in Academic Libraries," 198.

30. Nat Bruning, Annual Book Price Update (Contocook, N.H.: YBP Library Services, 2012), available online at www.ybp.com/book_price_update.html [accessed 12 September 2013].

31. Sue Polanka, "University Presses and Ebooks: A New Horizon," Online 36, no. 1 (Jan./Feb. 2012): 53-56.

32. Chris Armstrong and Ray Lonsdale, "Challenges in Managing E-Book Collections in UK Academic Libraries," Library Collections, Acquisitions, and Technical Services 29, no. 1 (Spring 2005): 33-50.

33. Walters, "E-books in Academic Libraries," 199; Marlie Wasserman, "10 Questions \& Tentative Answers: The State of E-book Publishing for University Presses," Information Standards Quarterly (Special Edition: Views of the E- book Renaissance) 23, no. 2 (Spring 2011): 12-15.

34. Kelly Lynch, "E-books: the Future for Publishers and Libraries," Collection Building 31, no. 2 (2012): 78-80.

35. Ibid., 79; Rafi Mohammed and Jan Eglan, "A New Perspective on E-Book Pricing," Publisher's Weekly 257, no. 2 (Jan. 11, 2010) 52.

36. American Association of University Presses, "About University Presses," available online at www.aaupnet.org/about-aaup/about-university-presses [accessed 10 June 2013].

37. Allen Kent et al., Use of Library Materials: The University of Pittsburgh Study (New York: Marcel Dekker, 1979). 